Łukasz Niesiołowski-Spanò

\title{
Jednak „dzieje starożytnej Palestyny”, czyli kilka uwag terminologicznych
}

Z wielkim zainteresowaniem przeczytałem artykuł księdza Juliana Warzechy ${ }^{1}$ stanowiący komentarz do mojego tekstu na temat współczesnej polskiej historiografii starożytnej Palestyny². Szczególną satysfakcję sprawiły mi te ustępy, w których autor wyrażał aprobatę dla moich stwierdzeń. Cieszy mnie, że pozostajemy zgodni w tak wielu merytorycznie kluczowych kwestiach dotyczących metody badawczej.

Z tonu artykułu księdza Warzechy można wywnioskować, że jest on optymistą w kwestii poziomu nauki polskiej i recepcji współczesnych nurtów badawczych w zakresie historiografii „biblijnego Izraela”. Ja deklarowałem się jako pesymista i w tej sprawie moje samopoczucie nadal nie ulega poprawie, choćby po lekturze artykułu Fabiana Tryla (nota bene historyka, a nie biblisty) opublikowanego na łamach „Ruchu Biblijnego i Liturgicznego" ". Właśnie dla tej przyczyny postanowiłem ponownie zabrać głos, gdyż - jak sądzę - nadal pozostają pewne niejasności, które warto uporządkować. Chodzi o terminologię.

Ksiądz Warzecha, pisząc o moim tekście, zauważa: „W tytule artykułu jednak mowa jest o dziejach Izraela, co - jak rozumiem - oznacza biblijnego Izraela. Autor na przemian mówi o historii Palestyny i tego właśnie biblijnego Izraela"4. Zacznę od bicia się w piersi: nie powinienem był używać w tytule swego tekstu słowa „Izrael”. Nie ma jednak racji ksiądz Warzecha pisząc, że na przemian używam określeń „Palestyna” i „biblijny Izrael”. Nazwa „Izrael” pojawia się w moim tekście jedynie raz (s. 87) i zapewne o ten właśnie jeden raz za dużo. Przedmiotem mojego zainteresowania była starożytna Palestyna, a nie Izrael, a tym mniej „biblijny Izrael”. A teraz wyjaśnienia.

${ }^{1}$ J. WARzecha, Pisanie dziejów Izraela nieco inaczej. Łukaszowi Niesiołowskiemu-Spanò w odpowiedzi, RBL 1 (2005), s. 63-65.

${ }^{2}$ Ł. NiesioŁowski-Spanò, Pisanie dziejów Izraela, RBL 2 (2003), s. 85-91.

${ }^{3}$ F. TrYL, Od Otniela do Saula. Poczatki państwowości izraelskiej, RBL 1 (2005), s. 5-28.

${ }^{4}$ J. Warzecha, Pisanie dziejów Izraela nieco inaczej..., art. cyt., s. 63. 
Mamy do czynienia z kilkoma terminami, nie dość wyraźnie od siebie odróżnianymi. Są to zatem określenia terytoriów: „biblijny Izrael”, „starożytna Palestyna”, „Kanaan”, „Ziemia Święta”, „Ziemia Obiecana”, „Juda”, „Izrael”, a także zamieszkującej je ludności: „Żydzi”, „Hebrajczycy”, „Judejczycy”, „Izraelici”.

Stosowany przez księdza Warzechę termin „biblijny Izrael” wydaje mi się kłopotliwy z kilku powodów. Przede wszystkim, może wprowadzać pewną dwuznaczność, czy mianowicie chodzi o terytorium, tak jak używane jest to określenie w biblijnych księgach opisujących władztwo Dawida i Salomona, czy też o lud Izraela, a zatem wspólnotę ludzi, których łączy według Biblii pochodzenie, historia i religia? Na domiar złego określenie „biblijny Izrael” mogłoby być używane również na określenie patriarchy Jakuba. To on jest przecież Izraelem.

Nie jestem jednak entuzjastą stosowania terminu „biblijny Izrael” w historiografii dla innej przyczyny. Biblia to zbiór ksiąg. Mają one rozmaity charakter, tworzone były w różnym czasie i odmiennych warunkach. Istnieją różne kanony biblijne, a zatem różne są i same Biblie. Skoro tak, to czy można mówić o jednym „biblijnym Izraelu”? A może „biblijny Izrael” Żydów, tworzony wyłącznie na podstawie kanonu żydowskiego, to byt odmienny od tego, jakim jest „,biblijny Izrael” katolików lub protestantów?

Co opisuje termin „biblijny Izrael”? Czy jego znaczenie jest niezmienne w czasie? Innymi słowy, czy można używać jednego terminu „biblijny Izrael”, pisząc o inwazji Ludów Morza i o działalności Apostołów? Czy „biblijny Izrael” w Księdze Ezechiela jest tym samym, czym w Księdze Rodzaju?

Określenia „Ziemia Święta” i „Ziemia Obiecana” nie przystają do tradycyjnej terminologii historiograficznej, gdyż są bardzo odległe od neutralnego zabarwienia, jakiego oczekiwalibyśmy od naukowych terminów. Nie dla każdego owa ziemia jest przecież święta, a tym bardziej nie każdemu obiecana. Choć określenia te pojawiają się niekiedy w nauce ${ }^{5}$, są to jednak dość rzadkie wypadki.

Inne terminy: „Kanaan”, „starożytna Palestyna”, ,Juda” i „Izrael” także mogą przysparzać kłopotów. Zarówno „Juda” jak i „Izrael” mają podwójne znaczenie, określają bowiem i bohatera Księgi Rodzaju, i państwo istniejące w pierwszej połowie I tysiąclecia p.n.e. na Bliskim Wschodzie. „Juda” to jednak nie tylko państwo ze stolicą w Jerozolimie, ale i plemię, którego dzieje obszernie relacjonuje literatura biblijna. Tożsamość imienia bohatera eponimicznego z politycznym bytem nie stanowi tu oczywiście kłopotu. Czy jednak można mówić o historii Izraela lub Judy w okresie, w którym

${ }^{5}$ Por. np. The New Encyclopedia of Archaeological Excavations in the Holy Land, red. E. Stern, t. 1-4, Jerusalem-New York-London 1993. 
państwa te nie istniały? Abstrahując tu od daty wyznaczającej początek owych państw, poważne pytanie budzi próba opisu dziejów okolic Samarii po 722 r. p.n.e. lub Jerozolimy po roku 586 p.n.e. Po tych datach nigdy więcej w starożytności nie spotkamy już politycznych tworów o nazwach Izrael i Juda. Czy zatem dzieje Izraela to jedynie dzieje państwa istniejącego w latach 1000-722 p.n.e.?

Pozostałe dwa określenia dotyczą wyłącznie położenia geograficznego. Zarówno „Kanaan” jak i „Palestyna” już w tekstach starożytnych stosowano na określenie pewnego obszaru. W stosunku do poprzednich terminów te dwa wydają się stosowniejsze do opisu dziejów omawianego regionu. Żaden z nich jednak nie jest idealny. „Kanaan” (za tym terminem optuje ksiądz Warzecha ${ }^{6}$ ) to określenie stosowane zarówno w Biblii, jak i w innych źródłach starożytnych (egipskich, fenickich, akadyjskich) ${ }^{7}$, ale dla autorów biblijnych „Kanaan” to wrogi obszar, który należało podporządkować, a ludność wytępić. Określenie „kananejski” staje się w Biblii synonimem opozycji wobec tego co hebrajskie i jahwistyczne. Ponadto termin „Kanaan” ( $k n$ 'n) stosowany był m.in. przez Fenicjan na określenie ich rodzimego terytorium, a zatem tego, co my zwykliśmy nazywać Fenicją. Czy zatem „Kanaan” to na pewno ta nazwa, której należałoby używać przy opisywaniu dziejów Hebrajczyków? Jak ponadto brzmiałaby ona w kontekście realiów hellenistycznych lub rzymskich? Jezus wędrujący z uczniami po osadach Kanaanu?

Na koniec „Palestyna”. Termin ten również może budzić wątpliwości. Po pierwsze, z uwagi na obecną sytuację polityczną w regionie. Nazwą „Palestyna” określamy bowiem terytoria zamieszkiwane i zarządzane przez Palestyńczyków w opozycji do państwa Izrael zamieszkiwanego i rządzonego przez Izraelczyków. Po drugie, nazwa „Palestyna” pojawiająca się po raz pierwszy u Herodota (III, 91), wywodzi się od nazwy Filistynów pozostających - jak stwierdza się w Biblii - w niemal ustawicznym konflikcie z Hebrajczykami. Nazwa ta stała się później obowiązującym określeniem prowincji rzymskiej, co również wprowadzać może pewne zamieszanie.

Pomimo tych wątpliwości właśnie termin „Palestyna”, a lepiej „starożytna Palestyna” wydaje się najbardziej odpowiedni przy historycznym opisie przeszłości regionu i ludów go zamieszkujących. Argument kwantytatywny, dotyczący upowszechnienia tego właśnie terminu w pracach historyków starożytnego Bliskiego Wschodu, nie jest oczywiście decydujący, choć dążenie do ujednolicenia terminologii byłoby uzasadnione. Rozstrzygające wydają się trzy przesłanki. Po pierwsze, termin „Palestyna” pochodzi

${ }^{6}$ Por. J. Warzecha, Pisanie dziejów Izraela nieco inaczej..., art. cyt., s. 63.

${ }^{7}$ P. C. Schmitz, Canaan (place), [w:] The Anchor Bible Dictionary, ed. in chief D. N. Freedman, New York 1997. 
z zewnątrz opisywanego bytu, będąc tym samym mniej uwikłany w ukryte znaczenia i ideologiczne niuanse. Po drugie, jest precyzyjnie geograficzny. W starożytności nigdy nie opisywał żadnego ludu ani niepodległego państwa, a jedynie określał obszar rozciągający się między Fenicją a Egiptem. Po trzecie wreszcie, nie ma kłopotów ze stosowaniem tego terminu jako nazwy geograficznej zarówno dla opisu rzeczywistości w epoce listów z Tell Amarna, jak i w czasach św. Hieronima.

A może nie historia miejsca, lecz historia ludzi? Może należałoby się pokusić o ukucie terminów dla historiografii wywodzących się z etnonimów? Czy można, analogicznie do sytuacji starożytnej Grecji ${ }^{8}$, mówić o dziejach jakiegoś konkretnego ludu?

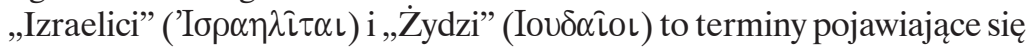
między innymi w Nowym Testamencie. Pierwsze z tych słów w oczywisty sposób pochodzi od biblijnego pojęcia Izraela, jako wspólnoty złączonej początkowo nie tyle jednolitą przynależnością etniczną, ile wspólną religią. Z czasem (w epoce hellenistycznej i rzymskiej) wyróżnikiem owej wspólnotowości w ramach terminu „Izraelici” coraz bardziej stawało się etniczne pochodzenie. Termin ten wyrasta jednak nie ze wspólnego doświadczenia lub historii, lecz z pewnego postulatu czy ideologicznego planu stworzenia jedności na gruncie wielości. Nie są to przecież potomkowie mieszkańców wielkiego państwa Dawida, w którego istnienie, a przynajmniej wielkość coraz częściej się wątpi. Tym bardziej nie są to potomkowie Izraela błądzącego przez czterdzieści lat po pustyni. Izraelici czasów Nowego Testamentu to wspólnota religijno-etniczna zbudowana nie na wspólnej kulturze, historii czy wspólnym państwie, lecz na fundamencie, jakim była Biblia. Jako taki, termin ten jest wybitnie ideologiczny i to w takim samym stopniu, jak zideologizowane jest jego źródło.

Innego rodzaju kłopot dotyczy terminu „Żydzi”. Pochodzi on bowiem od nazw geograficzno-politycznych. Hebrajski termin jehûdî pochodzi od nazwy perskiej prowincji jehû $\underline{d}$ (por. Ezd 7,14). Grecki termin - jak się wydaje - powstał na analogicznej zasadzie, mając za źródłosłów nazwę „Juda”. Skoro tak, to czy można mówić o „Żydach” w okresach poprzedzających istnienie prowincji jehû $\underline{d}$ albo w odniesieniu do obszarów niewchodzących w skład tejże prowincji? Na domiar złego sam termin „Żydzi” już w tekstach starożytnych nie zawsze jest precyzyjnie zdefiniowany. Passus z Józefa Flawiusza wystarczy tu za przykład:

${ }^{8}$ Zob. B. Bravo, E. WiPszycKa, Historia starożytnych Greków, t. 1, Warszawa 1988, t. 3, Warszawa 1992; Z. KuBIAK, Mitologia Greków i Rzymian, Warszawa 1997; tegoż, Literatura Greków i Rzymian, Warszawa 1999. 
„Zdobył także Hirkan miasta idumejskie: Adorę i Marisę, a ugiąwszy pod swoją władzę wszystkich Idumejczyków, pozwolił im zostać w tym kraju, pod warunkiem jednak, że poddadzą się obrzezaniu i będą żyli według praw żydowskich. Ci, skłonieni umiłowaniem ziemi ojczystej, poddali się obrzezaniu i pod każdym względem dostosowali swoje życie do obyczajów żydowskich. I od owego czasu byli już zawsze Żydami”".

„Żydzi” zdefiniowani według tego ustępu to wszyscy obrzezani, przestrzegający praw żydowskich, czyli zapewne religijnego prawa biblijnego. Kogo zatem dotyczyłaby historia Żydów w starożytności, gdyby za punkt wyjścia przyjąć taką definicję?

Podobnie jak w kwestii „biblijnego Izraela”, różnię się w poglądach od księdza Warzechy, który stosuje termin „Izraelici” w opozycji np. do Filistynów ${ }^{10}$. Jak rozumiem, ma na myśli „Lud Wybrany”, wspólnotę wiernych jahwistów, a nie mieszkańców północnego królestwa. Jeśli tak, to ten arbitralny wybór wzbudza mój niepokój. Mamy tu przecież do czynienia z użyciem terminu czysto ideologicznego. Mowa przecież o Izraelu stworzonym na piśmie, rękami propagatorów jahwizmu, a później judaizmu. Nigdy w istocie w tzw. czasach biblijnych nie istniał jeden, homogeniczny Lud Boży. W pierwszej połowie I tysiąclecia p.n.e. jahwiści koegzystowali z czcicielami Baala, monoteizm nie był ponadto jedyną formą jahwizmu (jeżeli w ogóle istniał już w powszechnej religijności prywatnej, a nie jedynie w tekstach profetycznych i teologicznych). Oczywiste jest, że nie można mówić wówczas, ale i jeszcze długo później, o jednolitości etnicznej. Izrael to umowna etykieta dla pewnej wyimaginowanej lub postulowanej wspólnoty, której granice musiały być dość płynne. Choćby Samarytanie - przecież nazywali się również Izraelem. Po czym zatem rozpoznać członka wspólnoty Izraela w X albo III wieku p.n.e.? Jeśli nie sposób wskazać jednolitej formuły definiującej ową wspólnotę (jako byt rzeczywisty, a nie jedynie pobożny postulat lub marzenie autorów biblijnych), to jednocześnie należałoby przyznać, że nie ma jednego Izraela. Skoro tak, to co opisuje ów termin?

Nie chciałbym być tu jednak źle zrozumiany. Choć powyższe dywagacje mogą trącić postmodernistycznym zwątpieniem i wydawać się dzieleniem włosa na czworo, to mamy w istocie do czynienia z kluczową kwestią dotyczącą terminologii badawczej. Wszystkie stosowane przez nas terminy pociągają za sobą szereg dodatkowych konotacji związanych choćby z aluzjami

${ }_{9}^{9}$ J. Flawiusz, Dawne dzieje Izraela, tł. Z. Kubiak, J. Radożycki, Warszawa 1993, 13, 257-258.

${ }^{10}$ Por. J. Warzecha, Pisanie dziejów Izraela nieco inaczej..., art. cyt., s. 65. 
i paralelnymi znaczeniami ${ }^{11}$. Dlatego terminy w rodzaju „Lud Boży” dla określenia mieszkańców starożytnej Palestyny w X wieku p.n.e. wydają się rażąco nieodpowiednie. Termin „Izraelici”, jeśli nie stosowany jedynie jako określenie mieszkańców północnego królestwa, zawiera w sobie ideologiczną skazę fikcyjności. Czy kiedyś, przed ukształtowaniem się judaizmu opartego na Torze, istniała w istocie grupa ludzi określająca się tym terminem? A jeśli tak, to jakie były kryteria przynależności do owej grupy?

Obawiam się, że z punktu widzenia metody, błędem jest używanie terminu, który występuje powszechnie w najbogatszym ze źródeł stosowanych przy rekonstrukcji dziejów starożytnej Palestyny, czyli Biblii. Postulować należałoby chyba posługiwanie się terminem bliższym neutralności ideologicznej. Z tej właśnie przyczyny sądzę, że przy opisywaniu całej ludności starożytnej Palestyny, którą łączyła wiara w Jahwe, lepszym terminem niż „Izraelici” jest termin „Hebrajczycy”. Oczywiście i wobec tego pojęcia istnieją liczne zastrzeżenia, lecz sądzę, że jest ono znacznie mniej obarczone bagażem znaczeń obecnych w terminach „Lud Izraela”, „Naród Wybrany” czy „Izraelici”.

Pisząc dzieje ludności zamieszkującej Palestynę w starożytności, jak sądzę, zręczniej jest mówić o dziejach starożytnej Palestyny, niż wymieniać różne grupy ludności ją zamieszkujące. W innym wypadku, by zawrzeć całość materii, w tytule monografii obejmującej okres np. od epoki listów z Tell el-Amarna do drugiego powstania żydowskiego należałoby wymienić kilkanaście nazw ludów.

Ksiądz Julian Warzecha twierdzi, że pisząc swój tekst wyważam otwarte drzwi czy strzelam kulą w płot $^{12}$ oraz że nie ma tam prawie nic nowego ${ }^{13}$. Nie wiem zbyt wiele o strzelaniu, lecz zgadzam się najzupełniej z tym, że zarówno w poprzednim artykule, jak i tutaj nie jestem nowatorem ani odkrywcą niczego nieznanego ${ }^{14}$. Niemniej jednak sądzę, że przedstawienie powyższych rozważań może przyczynić się do ożywienia dyskusji na tematy związane z terminologią naszych badań.

Wyjaśnienia wymaga jeszcze jedna opinia księdza Warzechy: „[Bibliści] koncentrują się też głównie na teologii, nad czym autor - oczywiście, że nie-

${ }^{11}$ Zastanawiające jest w tym kontekście, że historycy piszący o dziejach Polski nie dają swoim opracowaniom tytułów w rodzaju: „Historia Polaków”, „Historia Chrześcijan”, „Historia Sarmatów” lub „Historia Lechitów”.

${ }^{12}$ Por. J. Warzecha, Pisanie dziejów Izraela nieco inaczej..., art. cyt., s. 64.

${ }^{13}$ Por. tamże, s. 65.

${ }^{14}$ Por. P. R. Davies, In search of 'Ancient Israel', Sheffield 1992 (Journal for the study of the Old Testament. Supplement series, 148); K. W. Whitelam, Invention of Ancient Israel. The silencing of Palestinian history, London-New York 1996. 
słusznie - ubolewa" ${ }^{15}$. Nie ubolewam nad faktem, że bibliści zajmują się Biblią głównie z teologicznego punktu widzenia. Jest to fakt, który przytoczyłem jako jedną z głównych przyczyn słabości polskiej historiografii starożytnego Bliskiego Wschodu oraz starożytnej Palestyny w szczególności. Chciałbym - dla dobra rozwoju myśli w Polsce - by teologia kwitła, podobnie jak szereg innych nauk. Ograniczone zainteresowanie studiami nad Biblią jako dziełem literackim czy jako źródłem historycznym, a w efekcie słabość historiografii starożytnej Palestyny, jest jednak wynikiem między innymi koncentrowania się badaczy przede wszystkim na teologii, a nie na innych dziedzinach wiedzy. Trudno tu ubolewać, bo nie widzę powodu, dla którego historia, literaturoznawstwo czy antropologia miałyby być stawiane ponad teologię. Miałem w zamiarze jedynie stwierdzenie faktu, podobnie jak w wypadku innego argumentu dotyczącego historycznych uwarunkowań badań naukowych w epoce PRL.

Warszawa

ŁUKASZ NIESIOEOWSKI-SPANÒ

${ }^{15}$ J. WARZecha, Pisanie dziejów Izraela nieco inaczej..., art. cyt., s. 63. Nota bene, zwróciło moją uwagę stosowanie przez księdza Warzechę pierwszej osoby liczby mnogiej przy przedstawianiu własnych poglądów. Jeśli - jak rozumiem - oznacza to całą wspólnotę biblistów (polskich?), to dziwi nieco ich jednomyślność. 
